\title{
JNPH
}

Volume 7 No. 2 (Oktober 2019)

(C) The Author(s) 2019

\section{UJI EFEKTIFITAS KEMATIAN LARVA AEDES SP LARVASIDA DENGAN INFUSA DAUN JAMBU BIJI (PSIDIUM GUAJAVA LINN)}

\section{TEST EFFECTIVENESS OF DEATH LARVA AEDES SP WITH LARVASIDES INFUSA JAMBU SEED LEAF (PSIDIUM GUAJAVA LINN)}

\author{
RESVA MENISASTI, RADEN SUNITA, KRISYANELLA \\ POLITEKNIK KESEHATAN KEMENTRIAN KESEHATAN BENGKULU
}

\begin{abstract}
ABSTRAK
Latar Belakang: Penyakit demam berdarah dengue (DBD) merupakan salah satu masalah kesehatan masyarakat di Indonesia dengan jumlah penderitanya meningkat dan penyebarannya semakin luas. Lebih dari 2,5 miliar orang, lebih dari $40 \%$ dari populasi dunia berisiko dari demam berdarah. WHO saat ini memperkirakan ada 50-10.000 infeksi dengue di seluruh dunia setiap tahun. Di Indonesia penyakit DBD masih merupakan masalah kesehatan karena masih banyak daerah yang endemik. Daerah endemik DBD pada umumnya merupakan sumber penyebaran penyakit ke wilayah lain. Untuk membatasi penyebaran penyakit DBD diperlukan gerakan pemberantasan sarang nyamuk (PSN), pengasapan (fogging), dan larvasidasi.Tujuan Penelitian : Penelitian bertujuan untuk mengetahui pengaruh larutan ekstrak daun jambu biji (Psidium Guajava L.) dalam membunuh larva nyamuk Aedes sp pada konsentrasi 10\%, 20\% dan 30\%. Metode Penelitian : penelitian ini menggunakan metode quasy eksperimen. Dengan menggunakan 3 konsentrasi dan kontrol negatif serta kontrol positif dengan melakukan 5 kali pengulangan perlakuan. Hasil: pada hasil penelitian menunjukan bahwa kematian larva tertinggi terdapat pada konsentrasi 30\% sebanyak 12 ekor.
\end{abstract}

\section{Kata Kunci : Aedes sp, Ekstrak daun jambu biji (Psidium guajava Linn),Larvasida}

\begin{abstract}
Background: Dengue hemorrhagic fever (DHF) is one of the public health problems in Indonesia with the number of sufferers increasing and its spread becoming more widespread. More than 2.5 billion people, more than $40 \%$ of the world population are at risk from dengue fever. WHO currently estimates that there are 50-10,000 dengue infections worldwide each year. In Indonesia, DHF is still a health problem because there are still many endemic areas. DHF endemic areas are generally a source of disease spread to other regions. To limit the spread of DHF disease, it is necessary to eradicate mosquito nest (PSN), fogging, and larvasidation movements. Research Purpose: The study aims to determine the effect of guava leaf extract solution (Psidium Guajava L.) in killing Aedes sp mosquito larvae at a concentration of $10 \%, 20 \%$ and $30 \%$. Research Method: this research uses quasy experimental method. By using 3 concentrations and negative control and positive control by doing 5 repetitions of treatment. Results: The results of the study showed that the highest larval mortality was at a $30 \%$ concentration of 12 animals.
\end{abstract}




\section{Keywords: Aedes sp, Guava leaf extract (Psidium guajava Linn), Larvasida}

\section{PENDAHULUAN}

Penyakit demam berdarah dengue (DBD) merupakan salah satu masalah kesehatan mastarakat di Indonesia dengan jumlah penderitanya meningkat dan penyebarannya semakin luas. Lebih dari 2,5 miliar orang lebih dari $40 \%$ dari populasi dunia - sekarang berisiko dari demam berdarah. WHO saat ini memperkirakan mungkin ada 50-10.000 infeksi dengue di seluruh dunia setiap tahun.

Di Indonesia penyakit DBD masih merupakan masalah kesehatan karena masih banyak daerah yang endemik. Daerah endemik DBD pada umumnya merupakan sumber penyebaran penyakit ke wilayah lain. Untuk membatasi penyebaran penyakit DBD diperlukan gerakan pemberantasan sarang nyamuk (PSN), pengasapan (fogging), dan larvasidasi.

Salah satu cara pemberantasan larva Aedes $s p$ dengan cara larvasida dengan menggunakan pestisida, sebagai pengganti pestisida kimia sintetik adalah pestisida organik yang diperoleh dari tanaman. Jambu biji tersebar luas sampai ke Asia Tenggara termasuk Indonseia, sampai Asia Selatan, India dan Srilangka. Jambu biji termasuk tanaman perdu dan memiliki banyak cabang dan ranting serta batang pohon yang keras. Permukaan kulit luar pohon jambu biji berwarna coklat dan licin, apabila dikelupas akan terlihat permukaan kayunya basah. Bentuk daun pada umumnya berwarna bercorak bulat telur dengan ukuran yang agak besar. Bunganya kecil - kecil berwarna putih. Jambu biji (Psidium guajava L.) merupakan tumbuhan yang daunnya mengandung senyawa kimia antara lain tannin, saponin, flavonoid, eugenol ( minyak atsiri ), minyak lemak, dammar, zat samak, triterpenoid, dan asam afel. Yang kebanyakan daun jambu biji biasanya di gunakan sebagai obat tradisional salah satu diantaranya diare, sariawan, kembung pada anak-anak, dan lain-lain.

\section{METODE PENELITIAN}

Penelitian ini menggunakan desain quasy eksperimen. Penelitian ini dilaksanakan di Laboratorium Terpadu Poltekkes Kemenkes Bengkulu pada bulan Febuari 2017. Sampel penelitian merupakan sejumlah larva nyamuk Aedes $s p$ instar III.

\section{HASIL PENELITIAN}

Hasil uji larvasida pada efektifitas larvasida ekstrak infusa daun jambu biji (Psidium Guajava Linn) dilakukan 5 kali pengulangan dengan konsentrasi 30\%, 20\% dan $10 \%$. Pada penelitian setelah dilakukan pemaparan selama 24 jam didapatkan ratarata kematian pada gambar 1 berikut ini.

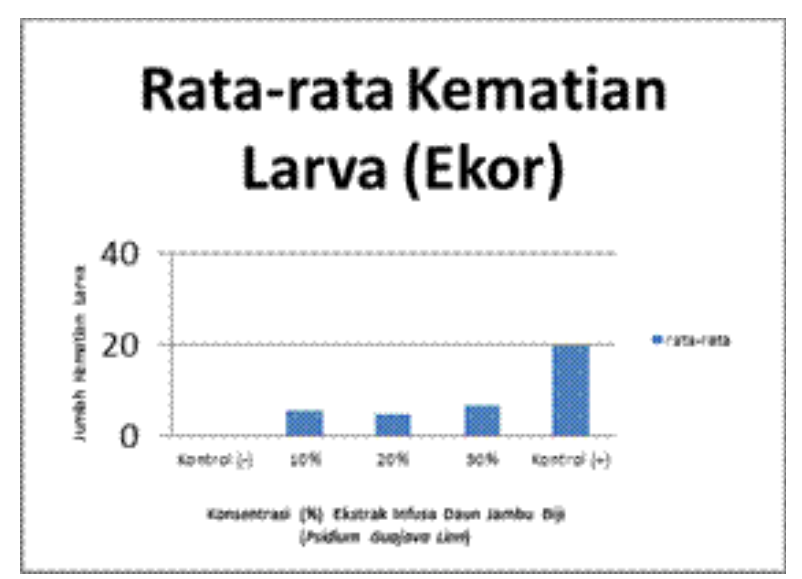

Gambar 1 tersebut menunjukan bahwa setelah dilakukan 5 kali pengulangan dengan total jumlah larva sebanyak 20 ekor setelah dilakukan kontak selama 24 jam kematian tertinggi terjadi pada konsentrasi $30 \%$.

\section{PEMBAHASAN}

Hasil uji larvasida menunjukkan bahwa peninigkatan jumlah kematian larva aedes $s p$ terjadi seiring dengan semakin meningkatnya konsentrasi larutan ekstrak infusa daun jambu biji (Psidium guajava Linn). Pada kelompok kontrol negatif tidak ditemukan larva aedes sp, sedangkan pada kelompok kontrol positif ditemukan kematian larva 100\%. Hal ini 
membuktikan bahwa kematian larva aedes $\mathrm{sp}$ pada kelompok perlakuan disebabkan oleh paparan ekstrak daun jambu biji (Psidium Guajava Linn).

Kematian larva aedes $s p$ dalam uji larvasida ini memperlihatkan tanda - tanda bahwa apabila larva di sentuh tidak bergerak menunjukkan larva tersebut telah mati. Dalam penelitian ini dilakukan dengan mengunakan 3 variasi konsentrasi. Variasi konsentrasi tersebut digunakan sebagai pembanding pada masing - masing perlakuan dan kontrol sebagai penentu keefektifan dari ketiga konsentrasi yang telah digunakan.

Abate merupakan nama dagang dari temephos dengan formulasi granules yaitu insektisida golongan organofosfat yang digunakan sebagai pengendalian larva Aedes $s p$ ditempat - tempat penampungan air. Abate sebaiknya diaplikasikan pada wadah penampungan air yang jarang di kuras hal ini di karenakan temephos mengandung senyawa beracun yang disebabkan oleh toksisitas tinggi dari xylene.

\section{KESIMPULAN}

Berdasarkan hasil penelitian efektifitas ekstrak infusa daun jambu biji (Psidium Guajava Linn) terhadap kematian larva aedes $s p$ di peroleh kesimpulan bahwa efektifitas larvasida ditemukan pada larutan ekstrak infusa daun jambu biji (Psidium Guajava Linn). Kematian larva tertinggi terhadap aedes spditemukan pada larutan ekstrak daun jambu biji (Psidium Guajava Linn) pada konsentrasi $30 \%$.

\section{SARAN}

Disarankan bagi masyarakat untuk untuk mencegah penularan penyakit DBD dengan memutuskan siklus hidup di tempat perindukan larva Aedes sp melalui pemanfaatan daun jambu biji (Psidium Guajava Linn) sebagai larvasida alami. Bagi peneliti berikutnya dapat melakukan penelitian serupa dengan memanfaatkan bahan alami ataupun dengan menggunakan larutan lain untuk digunakan.

\section{DAFTAR PUSTAKA}

Dwi Sunar Prasetyono. (2013). Daftar Tanda \& Gejala Ragam Penyakit. (Putri Erine Nareswati, Ed.) (2nd ed.). Yogyakarta: FlashBook.

Effectiviness Of Ethanol Extract Guava Leaf ( Psidium guajava L.) As Larvachidal To Aedes Aegypti Mosquito Richa Yuswantina, Sikni Retno K., Misni Rauhul Aini. (n.d.), 127, 1-8.

Fact, D. (2017). Dengue, 2010-2012..

Kemenkes RI. (2015). Pedoman Pengendalian Demam Berdarah Dengue Di Indonesia. Jakarta.

Oktiarni, D., Manaf, S., \& Suripno. (2012). Pengujian Ekstrak Daun Jambu Biji (Psidium guajava Linn .) Terhadap Penyembuhan Luka Bakar Pada Mencit ( Mus musculus ). GRADIEN Journal, $8(1), 752-755$.

Parimin. (2005). Jambu Biji (1st ed.). Jakarta: Penebar Swadaya.

T.Sembel, D. (2009). Entomologi Kedokteran. (J. Widiyatmoko, Ed.) (1st ed.). Yogyakarta: Andi Yogyakarta.

Widoyono. (2011). Penyakit Tropis. (R. Astikawati, Ed.) (2nd ed.). Jakarta: Erlangga.

Wowor, P. M. (n.d.). Uji efek ekstrak etanol daun jambu biji 371-378. 